\title{
In vitro Study of Plant Growth Promoting Methylotrophic Bacterial Consortium as a Plant Probiotics for Paddy
}

\author{
Ronak R. Prajapati*, Y.K. Jhala and R.V. Vyas \\ Department of Agricultural Microbiology and Bio-fertilizers project, B.A. Collage of \\ Agriculture, Anand Agricultural University, Anand-388110, Gujarat, India \\ *Corresponding author
}

\begin{tabular}{|c|c|}
\hline & A B S T R A C T \\
\hline Keywords & \multirow{5}{*}{$\begin{array}{l}\text { Three efficient native phyllospheric methylotrophic isolates selected for in vitro } \\
\text { compatibility test with existing rhizospheric methylotrophic reference cultures for } \\
\text { liquid consortium development for testing efficacy on paddy cv. Gurjari. Chess } \\
\text { medium found best for good growth and sporulation of isolates compared to other } \\
\text { media. Beneficial native methylotrophic bacteria inherited capacity of methane } \\
\text { degradation, have additional ability to promote plant growth through one or more } \\
\text { mechanisms. Among all individual isolates consortium were found maximum } \\
\text { potash solubilization efficiency, nifH gene presence and nitrogen fixation ability, } \\
\text { inhibitory effect on soil borne pathogenic fungi by producing protease, cellulase } \\
\text { and lipase enzymes, in vitro efficacy of individual and consortium application of } \\
\text { methylotrophic bacteria on rice growth. Consortium application showed } \\
\text { significant increase in seed germination, root length, shoot length and seedling } \\
\text { vigor index of seedlings compared to individual culture inoculation, viz. S. } \\
\text { saprophyticus, B. subtilis, B. methylotrophicus, B. aerius, P. illinoisensis and B. } \\
\text { megaterium respectively. }\end{array}$} \\
\hline $\begin{array}{l}\text { Compatibility, } \\
\text { Consortium, } \\
\text { Plant growth } \\
\text { promotion, } \\
\text { Liquid } \\
\text { formulation }\end{array}$ & \\
\hline Article Info & \\
\hline $\begin{array}{l}\text { Accepted: } \\
25 \text { April } 2017 \\
\text { Available Online: } \\
\text { 10 May } 2017\end{array}$ & \\
\hline & \\
\hline
\end{tabular}

\section{Introduction}

Extensive use of chemical fertilizers in farming assures high yield but simultaneously causes environmental problems. Because of this resurgence of interest for eco-friendly sustainable and organic agricultural practices is recently awaked (Esitken et al., 2006). The positive relationship between microorganisms and plants are known since time immemorial, wherein, both partners benefit from each other directly or indirectly. Bacteria are among the most abundant microorganisms that colonize plant leaves (i.e., the phyllosphere) and socalled "phyllobacteria" or "epiphytes".
These bacteria inhabit a harsh environment which is poor in nutrients and exposed to sun, wind and rain. In contrast to phyllosphere organisms, the rhizospheric microbes occur in the below-ground area and remaining in a dark and moist environment, which is relatively rich in organic nutrients. Most of these organic compounds (root exudates) are released by the growing cells of plants, the host organism for bacteria (Kutschera, 2007).

Food and Agriculture Organization (FAO) and World Health Organization (WHO) have 
developed an operational definition for beneficial bacteria as Probiotics, "Live microorganisms which when administered in adequate amounts confer a health benefit on the host." It should come as no surprise that humans are not only the organisms that benefited from relationships with the right kind of bacteria, but soil beneficial bacteria can also be called as probiotics of plants.

Researcher has reported isolations of PPFMs from plant materials, in particular from root and leaf surfaces (Anitha, 2010). Their association is proved with more than 70 plant species and makes them interesting to study as potential agents improving plant growth and suppressing disease. However, there are few reports focusing on these aspects in India. Certain isolates are known to produce auxins, cytokinins and vitamin B12 providing them as best PGPB (Plant Growth Promoting Bacteria). Interactions with the plant nitrogen metabolism mediated by bacterial urease and the possible role of this in seed germination physiology have also been described. To evaluate dual role of native methylotrophic isolates like methane consumer cum growth promoter to develop plant probiotics liquid formulation for rice crop, the present research work was planned and conducted.

\section{Materials and Methods}

\section{Consortium development}

\section{Sources of native methylotrophic bacterial isolates}

Rhizospheric methylotrophic bacterial isolates like Bacillus aerius AAU M-8, Paenibacillus illinoisensis AAU M-17, Bacillus megaterium AAU M-29 were collected from the Department of Agril. Microbiology, B. A. Collage of Agriculture, Anand Agricultural University, Anand and three rice native phylospheric methylotrophic isolates (Prajapati, et al., 2017 in printing) M-3, M-10 and M-15 were used for consortium development for paddy.

\section{Compatible test}

Each methylotrophic bacterial isolate was grown in AMS broth for 5-6 days. They were cross streaked on nutrient agar medium plates and their growth was checked after $48 \mathrm{hrs}$ of incubation. Native isolates $\mathrm{M}-1$ to $\mathrm{M}-15$, AAU M-8, AAU M-17 and AAU M-29 were tested for compatibility by cross streak assay in nutrient agar medium. To test the compatibility of M-29 with other cultures, the M-29 was streaked as a strip at one end of the plate and inoculated for 24 hours to form a thick growth (Sateesh and Sivasakthivelan, 2013).

\section{Consortium preparation}

All the native Phyllospheric and Rhizospheric methylotrophic bacterial isolates were grown separately in respective broth media (AMS) to ensure maximum resting structures (cyst/spore) formation. Determination of population density of each isolates in broth was done by direct microscopic count. Individual culture in specific proportion was mixed to reach population density of $5 \times 109$ in final product (Dabhi, et al., 2014). Longevity of the product monitored through determination of microbial population in the finished product at monthly interval up to 1 year (As per FCO gazette notification for introduction of NPK consortia biofertilizers, Dept. of Agriculture \& co-operative, Ministry of Agriculture, GOI vide S. O. 1181(E) dated 30.04.2014).

In vitro evaluation of PGP traits of methylotrophic bacterial consortium

\section{Detection of nifH gene}

Genomic DNA of all native diazotrophic bacterial isolates and standard strains were 
isolated using the protocol described Sambrook et al., (1989). Fragments of nifH genes were amplified by two PCR reaction. PCR was performed in PCR reaction mixture $(25 \mu \mathrm{l})$ containing $2.5 \mu \mathrm{l}$ Taq Buffer $(10 \mathrm{X})$, $0.5 \mu \mathrm{d}$ dNTPs (2.5 mM each) mix, $2.0 \mu \mathrm{l}$ Template DNA $(25 \mathrm{ng} / \mu \mathrm{l}), 0.4 \quad \mu \mathrm{l}$ Taq polymerase $(5 \mathrm{U} / \mu \mathrm{l}), \quad 17.8 \mu \mathrm{l}$ Millipore Sterilized Water using degenerated following primers (Poly et al., 2001) $1.0 \mu \mathrm{l}$ Primer 1 (Pol F- 5' TGCGAYCCSAARGCBGACTC $\left.3^{\prime}\right)$ and $1.0 \mu \mathrm{l}$ Primer 2 (Pol R5'ATSGCCATCATYTCRCCGGA 3') and the primers synthesized at MWG Bio-tech Pvt. Ltd., Germany. PCR was successful to amplify a 360 base pair (bp) nifH fragment from the 3 different native diazotrophic bacterial isolates. PCR reaction mixture was prepared from the stock solutions of each individual component. The reagents were mixed thoroughly by a short spin using microfuge. The tubes were placed in Mastercycler personal (Eppendorf) and subjected to PCR, according to the following protocol. Initial denaturation at $94^{\circ} \mathrm{C}$ for 5 min, Denaturation $94^{\circ} \mathrm{C}$ for $5 \mathrm{~min}$, annealing at $62^{\circ} \mathrm{C}$ for $1 \mathrm{~min}$, extension at $72{ }^{\circ} \mathrm{C}$ for 1 min, final extension step at $72{ }^{\circ} \mathrm{C}$ for $5 \mathrm{~min}$ were performed. PCR reactions were run for 30 cycles. PCR products were analyzed by gel electrophoresis with molecular marker DNA (100 bp ladder) of known molecular weight on $1.8 \%$ agarose gel at $80 \mathrm{~V}$ using $1 \mathrm{X}$ TAE buffer and ethidium bromide $(0.5 \mu \mathrm{g} / \mathrm{ml})$. Gels were visualized under UV light and photographed using gel documentation system.

\section{Nitrogen fixation}

The plant growth promoting effect showed by phyllospheric and rhizospheric methylotrophs is directly attributed to its capacity to fix atmospheric nitrogen into the forms utilized by plants. Isolates were inoculated into the nitrogen free broth containing sucrose as carbon source and cultures were grown at $30 \pm 2{ }^{\circ} \mathrm{C}$ for $5-7$ days and nitrogen fixation was measured by Micro-Kjehldahl method (Bremner, 1958). Sugar utilization was estimated by DNS method. The rate of nitrogen fixation was expressed as $\mathrm{mg}$ nitrogen fixed per gram of sucrose consumed.

\section{Phosphate solubilization capacity}

\section{Phosphate solubilization efficiency in solid medium}

All the isolates were spot inoculated on sperbor medium. Plates were incubated at $30+2^{\circ} \mathrm{C}$ and examined for the colonies showing clear zones of calcium released at 67 days (Jackson, 1973).

\section{Phosphate solubilization efficiency in liquid medium}

Erlenmeyer flasks $(250 \mathrm{ml})$ containing $100 \mathrm{ml}$ of the liquid PKVK medium were inoculated with $100 \mu \mathrm{l}$ of bacterial suspension (approx. $107 \mathrm{cfu} / \mathrm{ml}$ ). For each isolate three flasks were inoculated. The flasks were incubated on rotary shaker $(150 \mathrm{rpm})$ at $30+2^{\circ} \mathrm{C}$. After 3,5 and 7 days, measurement of $\mathrm{pH}$ using $\mathrm{pH}$ meter and liberated $\mathrm{P}$ following Vanadomolybdate method was carried out (Jha et al., 2009). The graph of OD versus concentration of phosphate in $\mu \mathrm{g}$ was plotted for the standard and samples were compared to calculate $\mathrm{P}$ concentration.

\section{Indole acetic acid (IAA) production}

In vitro IAA production by selected isolates was determined using the protocol described by Khalid et al., (2004). For this purpose, 10 ml Glucose Phosphate Broth (GPB) medium was prepared in $100 \mathrm{ml}$ Erlenmeyer flasks, autoclaved and cooled. L-Tryptophan was filter sterilized passing through $0.2 \mu \mathrm{m}$ membrane filter and added at desired 
concentration $(1 \mu \mathrm{g} / \mathrm{ml})$ to the liquid medium. The flasks were inoculated with $1.0 \mathrm{ml}$ of 3 days old bacterial broth $(107 \mathrm{CFU} / \mathrm{ml})$ and incubated at $30+2^{\circ} \mathrm{C}$ for $48 \mathrm{~h}$. Un-inoculated control was kept for comparison. After incubation, the contents were filtered through Whatman filter paper No. 2. For measuring IAA, $3.0 \mathrm{ml}$ of filtrate was taken in test tube and $2.0 \mathrm{ml}$ of Salkowski reagent was added. The contents in the test tubes were allowed to stand for $1 / 2 \mathrm{~h}$ for color development. Similarly, color was also developed in standard solutions of IAA. The intensity of color was measured at $535 \mathrm{~nm}$ by spectrophotometer. Standard curve was prepared and used to calculate IAA produced by methylotrophic isolates.

\section{ACC-deaminase activity}

Qualitative screening of bacterial isolates for ACC deaminase enzyme production was carried out based on their ability to use ACC (1-Aminocyclopropane-1-Carboxylate) as a sole nitrogen source in the sugar free minimal salt medium. Cultures were spot inoculated on petri plates containing DF salt minimal medium (Dworkin and Foster, 1958) supplemented with $3 \mathrm{mM}$ ACC substrate. Plates containing DF minimal medium without ACC served as negative control and with (NH4)2SO4 (2.0 gm/l) as a nitrogen source serve as positive control. The plates were incubated for 3-4 days at $30+2^{\circ} \mathrm{C}$. Growth of isolates on ACC supplemented plates was compared with positive and negative control plates. Isolates grown well on ACC plates were considered as ACC deaminase enzyme producers (Daun et al.,2009).

\section{Potash solubilization efficiency}

All the isolates were spot inoculated on Glucose Yeast Calcium agar medium $(\mathrm{GYCaA})$. Plates were incubated at $30+2{ }^{\circ} \mathrm{C}$ and examined for the colonies showing clear zones of calcium released at 6-7 days. Colonies showing clear zone were further inoculated on Alendreskov's media containing mica and feldspar as a raw insoluble potash substrate to check their potash mobilization activity (Hu et al., 2006).

\section{Biocontrol potential of native potential methylotrophic consortium}

\section{Bioassay against plant pathogenic fungi}

Methylotrophic isolates were tested in vitro for their biocontrol potential by dual inoculation technique (Foldes et al., 2000) against three fungal plant pathogens viz. Macrophomina sp., Fusarium sp. and Pythium sp. Each fungal pathogen was grown on the Potato Dextrose Agar (PDA) plate till it covered the whole surface of the agar plate. With the help of sterile cork borer, a agar disc having fungal growth from plate was taken and placed at the centre of the fresh PDA plate. Test bacterial culture suspension $(50 \mu \mathrm{l})$ was inoculated in the wells $3 \mathrm{~cm}$ away from fungal disc and kept for incubation at $30+2{ }^{\circ} \mathrm{C}$ for 7 days. Inhibition of fungal growth was recorded at 5th and 7th days after coincubation and compared with normal fungal growth.

\section{Siderophore production}

The production of siderophore by isolates was assessed through plate assay. Chrome Azurol $S$ blue agar medium (CAS) was used to detect siderophore production by the isolates as per method described by Alexander and Zuberer (1991). CAS medium (1 ltr) was prepared by dissolving $60.5 \mathrm{mg}$ Chrome Azurol S (CAS) (HiMedia) in $50 \mathrm{ml}$ water and mixed with 10 $\mathrm{ml}$ iron (III) solution ( $1 \mathrm{mM} \mathrm{FeCl} 3.6 \mathrm{H} 2 \mathrm{O}$ in $10 \mathrm{mM} \mathrm{HCl}$ ). With continuous stirring, the solution was slowly added to $72.9 \mathrm{mg}$ hexadecyl trimethyl ammonium bromide 
(HDTMA) dissolved in $40 \mathrm{ml}$ water. The resultant dark blue liquid was autoclaved.

In $100 \mathrm{ml}$ of $10 \mathrm{XMM}$ salt broth, $30.2 \mathrm{~g}$ of PIPES, $18 \mathrm{~g}$ agar and $750 \mathrm{ml}$ double distilled water were added. $\mathrm{pH}$ of the medium was adjusted to 6.8 by the addition of $\mathrm{NaOH}$ solution (w/v) and autoclaved. After cooling of medium up to $50^{\circ} \mathrm{C}$, the previously prepared sterile CAS dye solution was added rolling down from glass wall of flask with gentle agitation to avoid formation of foam or bubble and uniform mixing of two liquids. The medium was poured into sterile petri plates. The plates were stored in refrigerator at $4^{\circ} \mathrm{C}$ till used. The overnight grown test bacterial cultures were spot inoculated on individual CAS plates and incubated at $30+2^{\circ} \mathrm{C}$ for $24 \mathrm{~h}$. The cultures showing yellow to orange coloured ring around the colonies were considered as siderophore production positive.

\section{Production of cell wall degrading enzymes}

The lipolytic activity was determined by streaking isolates on Tributyrin agar plates (Lawrence et al., 1967) in laboratory and recorded growth. The protease production was determined using skimmed milk agar. Bacterial cells were spot inoculated and incubated for 2 days at $30+2^{\circ} \mathrm{C}$. Proteolytic activity was identified by clear zone around the colony (Smibert and Krieg, 1994). The cellulase activity was determined by streaking isolates on cellulose agar plate and after incubation assayed as per method suggested by Ibrahim and El- diwani (2007).

\section{PGPR effects of proven isolates consortium on rice cv. Gurjari}

Rice seeds cv. Gurjari were surface sterilized by washing in $95 \%$ ethanol solution for 5 min, $0.1 \% \mathrm{HgCl} 2$ solution for $2 \mathrm{~min}$ and rinsed thoroughly with distilled water 3-5 times. Thoroughly washed seeds were kept on previously sterilized filter paper sheet placed in Petri plates and incubated at room temperature for 5 days, seed germination was examined at $96 \mathrm{hrs}$ interval and germination percentage were calculated. In vitro efficacy of isolates was tested on solid water agar in tubes on Rice cv. Gurjari. Surface sterilized seed were treated with $0.01 \mathrm{ml}$ of previously grown starter cultures of methylotrophic isolates for $30 \mathrm{~min}$. Individual treated seeds were inoculated on butt agar $(1 \%)$ and allowed to grow in a growth chamber at $28 \pm 2^{\circ} \mathrm{C}$. Control seeds without treatment were also used as check and each treatment was repeated three times. After 10 to 12 days of incubation the plantlets were removed carefully from water agar and root length, shoot length and fresh weight were measured. Vigor Index (VI) has been calculated using following formula (Haque et al., 2007).

Vigor Index (VI) = Germination \% X (Root length + Shoot Length)

\section{Results and Discussion}

\section{Consortium development}

\section{In vitro compatibility of chosen phyllospheric and rhizospheric methylotrophic bacterial isolates for consortium}

An important prerequisite for successful development of microbial culture mixture (consortium) depend on the compatibility (tolerance) of co-inoculated microorganisms. Three native rhizospheric methylotrophic bacterial cultures ( $B$. aerius AAU M-8, $P$. illinoisensis AAU M-17 and B. megaterium AAU M-29) already proven as methane degrader (Jhala et al., 2015) as well as proved as good plant growth promoter were tested for compatibility with three phyllospheric methylotrophic bacterial isolates $(S$. 
saprophyticus, B. subtilis and $B$. methylotrophicus) on Nutrient agar media in vitro. All the bacterial cultures were found compatible with each other (Plate 4.8) and were selected for preparing a rhizospheric and phyllospheric methylotrophic bacterial liquid consortium for trapping or capturing emitted methane as a sole carbon source from paddy field and feedback provides plant growth promoting substances for growth and development paddy.

\section{Consortium preparation}

All phyllospheric and rhizospheric methylotrophic cultures were grown separately in five different medium viz., Ammonium mineral salt (NMS), Nutrient broth (NB), Chess medium, Lurial broth (LB) and Rocket medium respectively, to ensure maximum sporulation. Result showed that among above five medium Luria broth (LB) showed maximum growth $(1.78 \times 106)$ but in case of spore formation chess medium showed fast sporulation compared to other medium $(1.96 \times 107)$ (Table-4.16, Plate 4.9). Chess medium was employed for development of phyllospheric and rhizospheric methylotrophic bacterial consortium. For determination of population density of each isolates in broth direct microscopic count was carried out in neuberger's chamber. Individual culture when obtained population density of 5 x 109 $(\mathrm{cfu} / \mathrm{ml})$ where stored at room temperature in laboratory. It was observed that bacteria has no inhibitory effect on each other in consortium indicating all chosen cultures used in consortium preparation were compatible with each other.

In vitro evaluation of liquid plant probiotic properties of methylotrophic consortium

Detection of nifH gene: All three native chosen phyllospheric methylotrophic isolates
S. saprophyticus, B. subtilis and $B$. methylotrophicus gave single band of $\sim 360$ bp indicating these isolates have presence of nif gene providing capability to fix atmospheric nitrogen (Plate 4.10). The nifH gene is widely used as marker gene for screening nitrogen fixing prokaryotes in soil. Jhala (2015) has already reported nifH in native methylotrophic bacteria of Gujarat like Bacillus aerius AAU M 8 (Accession no. $\mathrm{KC787582)}$ the same bacterium is also incorporated as rhizospheric methylotrophic culture in formulated consortium for rice field testing on cv. Gurjari.

\section{Nitrogen fixing capacity}

The results of this experiment are mentioned in Table 4.17. All the isolates and consortium were confirmed to have ability of fixing atmospheric nitrogen. It was revealed from the results that nitrogen fixing potentiality of these isolates ranged from 5.56 to $17.06 \mathrm{mg}$ $\mathrm{Ng}-1$ of sucrose consumed and consortium showed the highest nitrogen fixation capacity (17.06 mg Ng-1 of sucrose consumed) followed by $B$. methylotrophicus, $S$. saprophyticus and B. subtilis (9.70, 7.79 and $5.56 \mathrm{mg} \mathrm{N} / \mathrm{g}$ of sucrose consumed respectively). Satapute et al., 2012 studied Bacillus subtilis strain AS-4 free living nitrogen fixing bacteria that could be exploited as soil inoculants and can be used for nitrogen fixation in soil for long run, ecofriendly and cost ineffective.

\section{Phosphate solubilization capacity}

\section{Phosphate solubilization efficiency in Solid medium}

All the tested isolates and their consortium were studied for phosphate solubilization capacity on Sperber's agar media. Methylotrophic consortium (combine inoculation) showed the maximum 
solubilization zone $(5 \mathrm{~mm})$ followed by individual inoculation of $S$. saprophyticus, $B$. subtilis, B. aerius, $P$. illinoisensis and $B$. megaterium (Table 4.18).

Phosphate solubilization efficiency in liquid medium

Data regarding phosphate solubilization, all the strains solubilized and released $\mathrm{P}$ from tri calcium phosphate (TCP), S. saprophyticus recorded maximum phosphate solubilization with increasing the time interval (30, 64 and $122 \mu \mathrm{g} / \mathrm{ml}$ at 2,4 and 6 DAI respectively) followed by other strains, B. subtilis (15 and $18 \mu \mathrm{g} / \mathrm{ml}$ at 4 and 6 DAI respectively), $B$. methylotrophicus $(7,13$ and $95 \mu \mathrm{g} / \mathrm{ml}$ at 2,4 and 6 DAI respectively), B. aerius (20, 27 and $47 \mu \mathrm{g} / \mathrm{ml}$ at 2, 4 and 6 DAI respectively), $P$. illinoisensis $(17,25$ and $48 \mu \mathrm{g} / \mathrm{ml}$ at 2, 4 and 6 DAI respectively) and $B$. megaterium $(15,25$ and $54 \mu \mathrm{g} / \mathrm{ml}$ at 2, 4 and 6 DAI respectively) while methylotrophic consortium showed maximum phosphate solubilization with increasing duration $(49,49$ and $80 \mu \mathrm{g} / \mathrm{ml}$ at 2 , 4 and 6 DAI respectively) as compared to individuals Table 4.19. The results indicated that methylotrophic consortium having capacity to utilize atmospheric methane as carbon and energy source, additionally have capacity to convert the unavailable phosphorus to available form for crop.

\section{Indole 3-Acetic Acid (IAA) production}

All methylotrophic isolates and their consortium were grown in Glucose Phosphate Broth supplemented with $0.5 \mu \mathrm{g} / \mathrm{ml}$ of tryptophan for IAA production. With increasing the incubation time viz., 2, 4 and 6 DAI increase in the IAA concentration $(\mu \mathrm{g} / \mathrm{ml})$ ranging from 2.3-5.2, 3.4-7.6 and 4.7$12.2 \mu \mathrm{g} / \mathrm{ml}$ respectively, was observed. Among all treatments, consortium having $(S$. saprophyticus + B. subtilis $+B$. methylotrophicus, B. aerius $+P$. illinoisensis $+B$. megaterium) produced maximum IAA (5.2, 7.6 and $12.2 \mu \mathrm{g} / \mathrm{ml}$ at 2,4 and 6 DAI respectively) followed by individual inoculum of $S$. saprophyticus $(3.3,6.6$ and $10.5 \mu \mathrm{g} / \mathrm{ml}$ at 2, 4 and 6 DAI respectively), B. subtilis (4.3, 6.4 and $8.0 \mu \mathrm{g} / \mathrm{ml}$ at 2,4 and 6 DAI respectively) and $B$. methylotrophicus (2.7, 5.9 and $9.5 \mu \mathrm{g} / \mathrm{ml}$ at 2,4 and 6 DAI respectively) as well as standard cultures $B$. aerius AAU M $8(2.3,3.4$ and $4.7 \mu \mathrm{g} / \mathrm{ml}$ at 2 , 4 and 6 DAI respectively), $P$. illinoisensis AAU M 17 (4.1, 6.4 and $4.8 \mu \mathrm{g} / \mathrm{ml}$ at 2, 4 and 6 DAI respectively) and $B$. megaterium AAU M $29(3.1,5.4$ and $6.7 \mu \mathrm{g} / \mathrm{ml}$ at 2,4 and 6 DAI respectively) Table 4.20 .

These results showed that combined inoculation (consortium) of native methylotrophic six isolates may have capacity to improve plant growth. Many phyllospheric and rhizospheric microorganisms are able to synthesize and secrete auxin, primarily IAA due to which they influence the growth of the plants. Yim et al., (2010) carried out quantitative analysis of IAA using Salkowski reagent from culture liquids of the Methylobacterium strains CBMB20 and CBMB110 in the presence of L-tryptophan and obtained 2.33 and $4.03 \mu \mathrm{g} / \mathrm{ml}$ respectively after 5 days of inoculation.

\section{Measurement of ACC-deaminase activity}

All the methylotrophic bacterial isolates and their consortium were found to grow luxuriously on plates containing (NH4)2SO4 as nitrogen source, whereas, grew poorly on plates containing nitrogen free MS media, moreover, combined inoculum (consortium), $B$. subtilis, $B$. aerius AAU M 8 and $B$. megaterium AAU M 29 showed luxurious growth on plates having ACC as sole source of nitrogen showing their ability to produce enzyme ACC deaminase (Table 4.21). 
Table.1 Effect of different synthetic medium on sporulation after $72 \mathrm{hrs}$ inoculation of methylotrophic bacteria

\begin{tabular}{|c|c|c|c|}
\hline \multirow{2}{*}{$\begin{array}{c}\text { Sr. } \\
\text { No. }\end{array}$} & Synthetic medium & $\begin{array}{c}\text { Microscopic } \\
\text { count }\end{array}$ & Plate count \\
\cline { 3 - 4 } & & Cells/ml & CFU/ml \\
\hline $\mathbf{1}$ & Ammonium mineral salt (AMS) & $1.78 \times 10^{6}$ & $2.12 \times 10^{6}$ \\
\hline $\mathbf{2}$ & Nutrient broth (NB) & $1.52 \times 10^{6}$ & $1.69 \times 10^{6}$ \\
\hline $\mathbf{3}$ & Chess medium & $1.11 \times 10^{6}$ & $1.56 \times 10^{7}$ \\
\hline $\mathbf{4}$ & Luria broth (LB) & $1.91 \times 10^{6}$ & $2.48 \times 10^{5}$ \\
\hline $\mathbf{5}$ & Rocket medium & $1.46 \times 10^{6}$ & $1.89 \times 10^{6}$ \\
\hline
\end{tabular}

Table.2 In vitro nitrogen fixation capacity of methylotrophic isolates

\begin{tabular}{|c|c|}
\hline Isolate & $\begin{array}{c}\text { Nitrogen fixation capacity } \\
\text { mg N/g of sucrose consumed }\end{array}$ \\
\hline S. saprophyticus & 7.79 \\
\hline B. subtilis & 5.56 \\
\hline B. methylotrophicus & 9.70 \\
\hline Consortium & 17.06 \\
\hline
\end{tabular}

Table.3 Solubilization of tri-calcium phosphate by methylotrophic isolates

\begin{tabular}{|c|c|}
\hline Isolate & $\begin{array}{c}\text { TCP solubilization } \\
\text { Zone }(\mathbf{m m})\end{array}$ \\
\hline S. saprophyticus & 3 \\
\hline B. subtilis & 2 \\
\hline B. methylotrophicus & 3 \\
\hline B. aerius AAU M 8 & 3 \\
\hline P. illinoisensis AAU M 17 & 2 \\
\hline B. megaterium AAU M 29 & 3 \\
\hline Consortium & 5 \\
\hline
\end{tabular}


Table.4 Solubilization of tri-calcium phosphate by methylotrophic isolates

\begin{tabular}{|l|c|}
\hline \multicolumn{1}{|c|}{ Isolate } & TCP solubilization Zone (mm) \\
\hline S. saprophyticus & 3 \\
\hline B. subtilis & 2 \\
\hline B. methylotrophicus & 3 \\
\hline B. aerius AAU M 8 & 3 \\
\hline P. illinoisensis AAU M 17 & 2 \\
\hline B. megaterium AAU M 29 & 3 \\
\hline Consortium & 5 \\
\hline
\end{tabular}

Table.5 In vitro phosphate solubilization efficiency of isolates

\begin{tabular}{|l|c|c|c|}
\hline \multirow{2}{*}{ Isolates } & At 2 DAI & At 4 DAI & At 6 DAI \\
\cline { 2 - 4 } & $\mathbf{P} \boldsymbol{\mu g} / \mathbf{m l}$ & $\mathbf{P ~} \boldsymbol{\mu g} / \mathbf{m l}$ & $\mathbf{P} \boldsymbol{\mu g} / \mathbf{m l}$ \\
\hline Initial & - & - & - \\
\hline S. saprophyticus & 30 & 64 & 122 \\
\hline B. subtilis & ND & 15 & 18 \\
\hline B. methylotrophicus & 7 & 13 & 95 \\
\hline B. aerius AAU M 8 & 20 & 27 & 47 \\
\hline P. illinoisensis AAU M 17 & 17 & 25 & 48 \\
\hline B. megaterium AAU M 29 & 15 & 25 & 54 \\
\hline Consortium & 49 & 49 & 80 \\
\hline
\end{tabular}

Note: ND-not detected

Table.6 In vitro IAA production efficiency of methylotrophic isolates

\begin{tabular}{|l|c|c|c|}
\hline \multirow{2}{*}{\multicolumn{1}{|c|}{ Isolate }} & \multicolumn{3}{c|}{ IAA concentration $(\boldsymbol{\mu g} / \mathbf{m l})$} \\
\cline { 2 - 4 } & 2 DAI & 4 DAI & 6 DAI \\
\hline S. saprophyticus & 3.3 & 6.6 & 10.5 \\
\hline B. subtilis & 4.3 & 6.4 & 8.0 \\
\hline B. methylotrophicus & 2.7 & 5.9 & 9.5 \\
\hline B. aerius AAU M 8 & 2.3 & 3.4 & 4.7 \\
\hline P. illinoisensis AAU M 17 & 4.1 & 6.4 & 4.8 \\
\hline B. megaterium AAU M 29 & 3.1 & 5.4 & 6.7 \\
\hline Consortium & 5.2 & 7.6 & 12.2 \\
\hline
\end{tabular}

Table.7 In vitro ACC deaminase activity of isolates

\begin{tabular}{|l|c|}
\hline \multicolumn{1}{|c|}{ Isolates } & ACC deaminase activity \\
\hline S. saprophyticus & + \\
\hline B. subtilis & ++ \\
\hline B. methylotrophicus & ++ \\
\hline B. aerius AAU M 8 & ++ \\
\hline P. illinoisensis AAU M 17 & + \\
\hline B. megaterium AAU M 29 & +++ \\
\hline Consortium & +++ \\
\hline
\end{tabular}

Note: +++ strong, ++ moderate, - absent 
Table.8 In vitro potash mobilization activity of isolates

\begin{tabular}{|l|c|}
\hline \multirow{2}{*}{\multicolumn{1}{|c|}{ Isolates }} & $\begin{array}{c}\text { Potash solubilization efficiency } \\
\text { Zone diameter (mm) }\end{array}$ \\
\cline { 2 - 3 } & Alendreskov's (mica) media \\
\hline S. saprophyticus & - \\
\hline B. subtilis & 3 \\
\hline B. methylotrophicus & 3 \\
\hline B. aerius AAU M 8 & 4 \\
\hline P. illinoisensis AAU M 17 & - \\
\hline B. megaterium AAU M 29 & 4 \\
\hline Consortium & 4 \\
\hline
\end{tabular}

Table.9 Biocontrol activity of potential methylotrophic isolates against plant pathogenic fungi

\begin{tabular}{|c|c|c|c|c|}
\hline \multirow{2}{*}{ Isolate } & \multicolumn{3}{|c|}{ Growth inhibition of test pathogenic fungi } \\
\cline { 2 - 4 } & $\begin{array}{c}\text { Macrophomina } \\
\text { spp. }\end{array}$ & $\begin{array}{c}\text { Pythium } \\
\text { spp. }\end{array}$ & $\begin{array}{c}\text { Rhizoctonia } \\
\text { spp. }\end{array}$ & $\begin{array}{c}\text { Fusarium } \\
\text { spp. }\end{array}$ \\
\hline S. saprophyticus & ND & ND & ND & ND \\
\hline B. subtilis & - & + & - & + \\
\hline B. methylotrophicus & + & + & + & + \\
\hline B. aerius AAU M 8 & + & + & + & + \\
\hline P. illinoisensis AAU M 17 & - & - & - & + \\
\hline B. megaterium AAU M 29 & + & + & + & + \\
\hline Consortium & + & + & + & + \\
\hline
\end{tabular}

Note: ND- not detected, + Detected

Table.10 In vitro siderophore production activity of isolates

\begin{tabular}{|c|c|}
\hline Isolates & $\begin{array}{c}\text { Siderophore production on } \\
\text { CAS agar medium }\end{array}$ \\
\hline S. saprophyticus & ND \\
\hline B. subtilis & + \\
\hline B. methylotrophicus & + \\
\hline B. aerius AAU M 8 & + \\
\hline P. illinoisensis AAU M 17 & + \\
\hline B. megaterium AAU M 29 & + \\
\hline Consortium & ++ \\
\hline
\end{tabular}

Note: ND- not detected 
Table.11 Cell wall degrading enzyme activity

\begin{tabular}{|c|c|c|}
\hline Isolates & Lipase & Protease \\
\hline S. saprophyticus & + & ND \\
\hline B. subtilis & + & ND \\
\hline B. methylotrophicus & ND & + \\
\hline B. aerius AAU M 8 & ND & ND \\
\hline P. illinoisensis AAU M 17 & ND & ND \\
\hline B. megaterium AAU M 29 & + & ND \\
\hline Consortium & + & ND \\
\hline
\end{tabular}

Note: ND- not detected
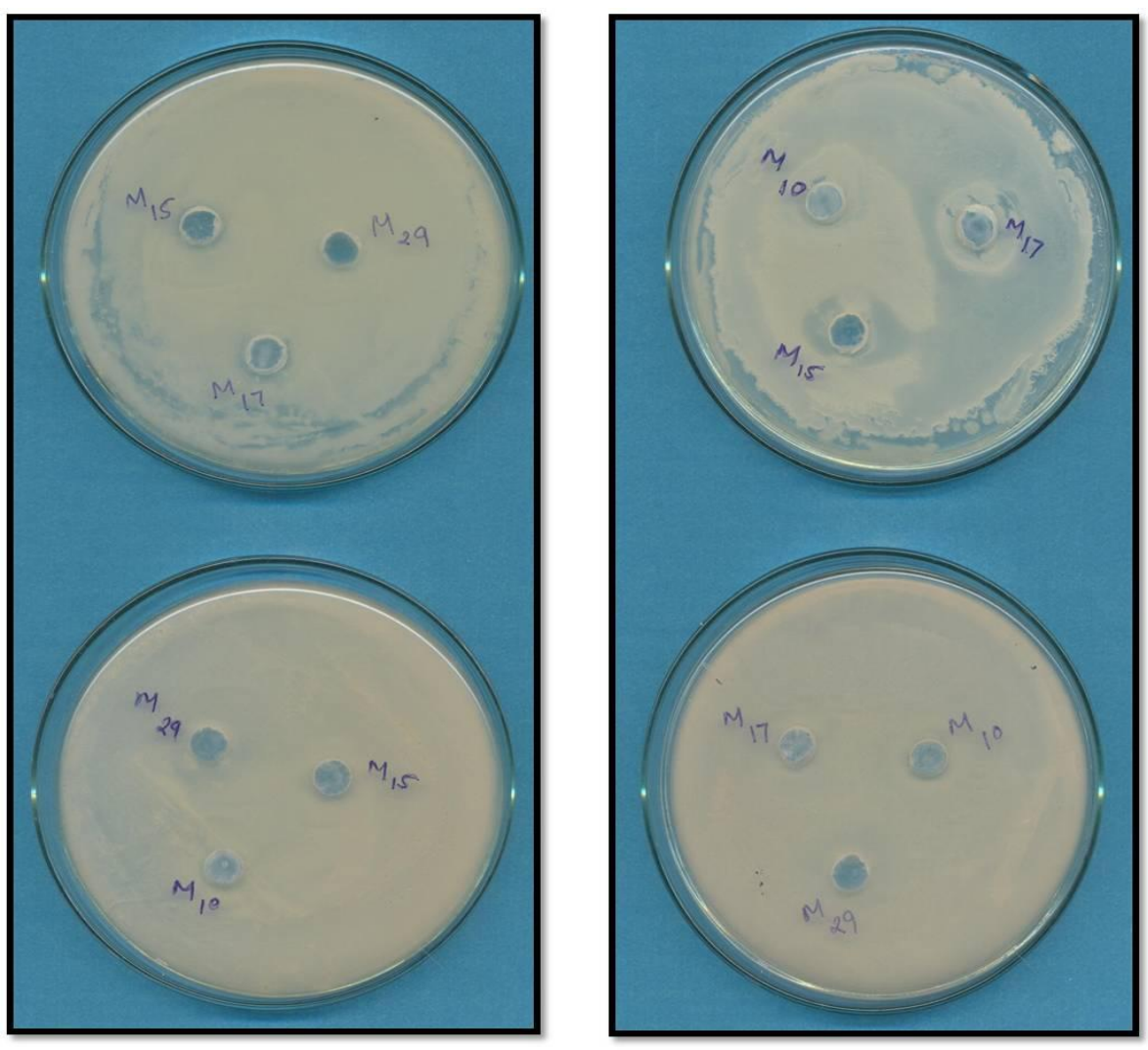

Plate.1 In vitro compatibility of phyllospheric and rhizospheric methylotrophic isolates on $\mathrm{N}$-agar 
Table.12 In vitro effect of methylotrophs on rice $c v$. Gurjari at 12 DAI

\begin{tabular}{|c|c|c|c|c|}
\hline Treatment & $\begin{array}{c}\text { Germination } \\
\text { percentage } \\
(\%)\end{array}$ & $\begin{array}{l}\text { Root } \\
\text { length } \\
(\mathrm{cm})\end{array}$ & $\begin{array}{c}\text { Shoot } \\
\text { length } \\
\text { (cm) }\end{array}$ & $\begin{array}{c}\text { Seedling vigor } \\
\text { Index }\end{array}$ \\
\hline Control & 80 & 3.50 & 7.90 & 684.0 \\
\hline S. saprophyticus AAU M 3 & 90 & 6.00 & 12.00 & 1620.0 \\
\hline B. subtilis AAU M 10 & 100 & 4.00 & 11.00 & 1500.0 \\
\hline B. methylotrophicus AAU M 15 & 100 & 6.50 & 11.70 & 1820.0 \\
\hline B. aerius AAU M 8 & 100 & 6.00 & 12.20 & 1820.0 \\
\hline P. illinoisensis AAU M 17 & 100 & 6.50 & 11.00 & 1750.0 \\
\hline B. megaterium AAU M 29 & 100 & 5.50 & 11.70 & 1720.0 \\
\hline Consortium & 100 & 7.00 & 12.7 & 1970.0 \\
\hline S.Em. \pm & - & 0.135 & 0.157 & - \\
\hline CD at $5 \%$ & - & 0.395 & 0.462 & - \\
\hline $\mathrm{CV} \%$ & - & 4.78 & 2.80 & - \\
\hline
\end{tabular}
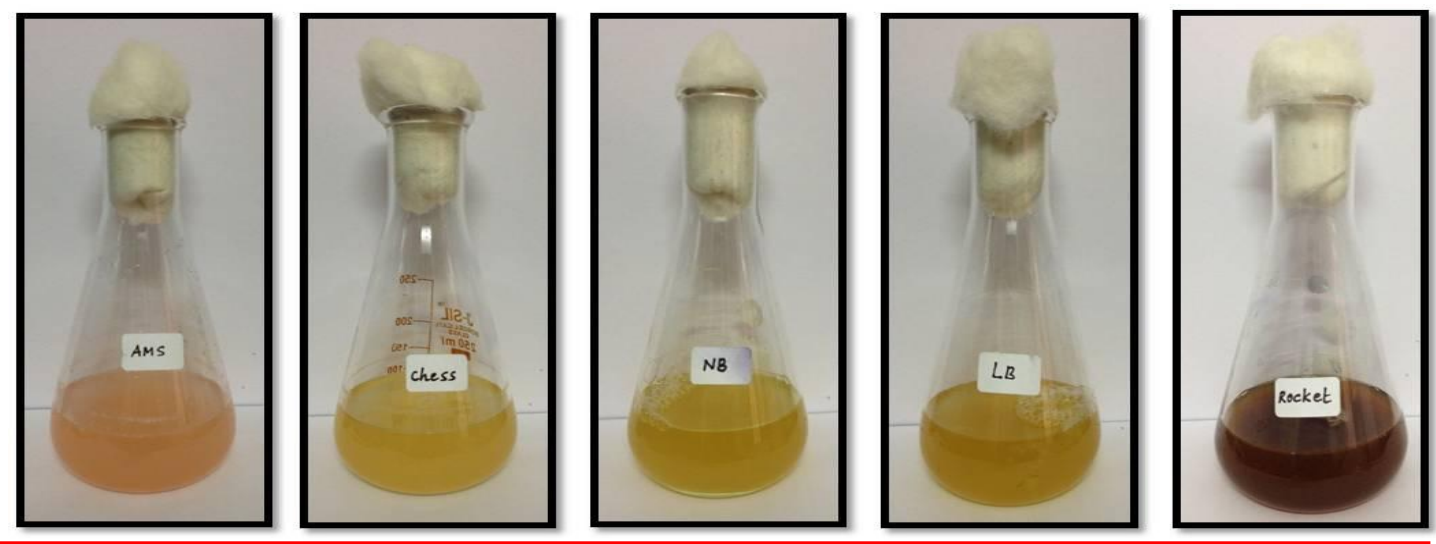

Plate.2 Different synthetic liquid media used for sporulation of methylotrophic bacterial liquid consortium.

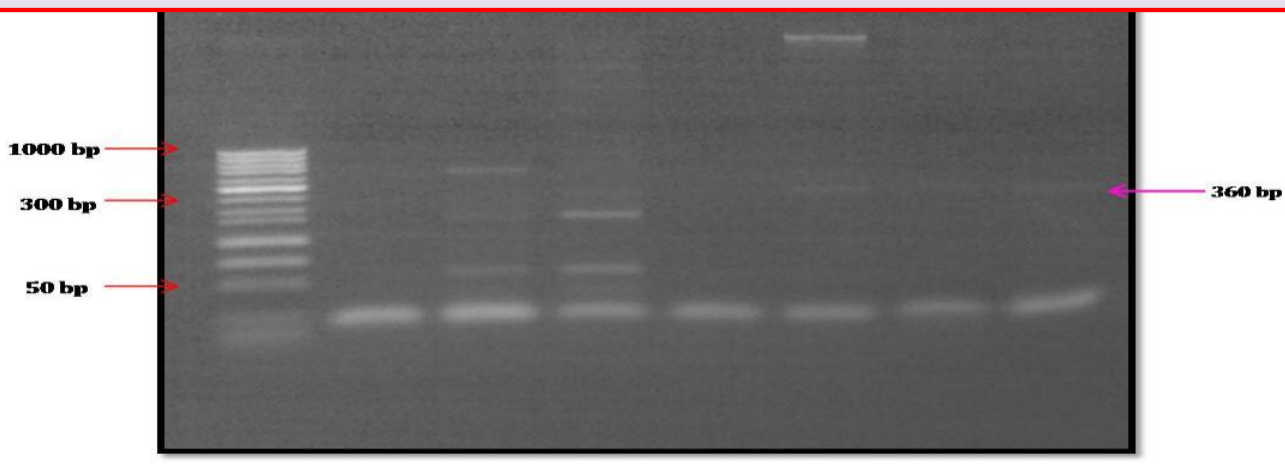

Plate.3 Amplification of the nitrogen fixation (nifH) gene from native phylospheric methylotrophic bacterial isolates with reference strains using degenerated universal nifH gene primer. Line: 1. M-10, 2. M-3, 3. M-15 and diazotrophic reference strains (R) MTCC-446 (A. chroococcum), MTCC-2306 (A. lipoferum) 

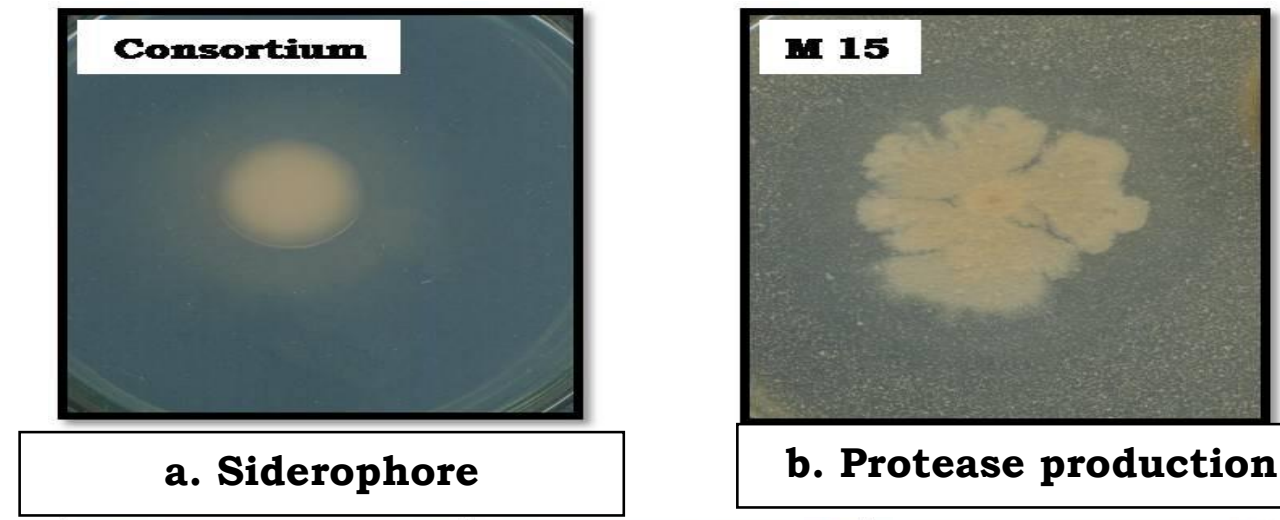

b. Protease production

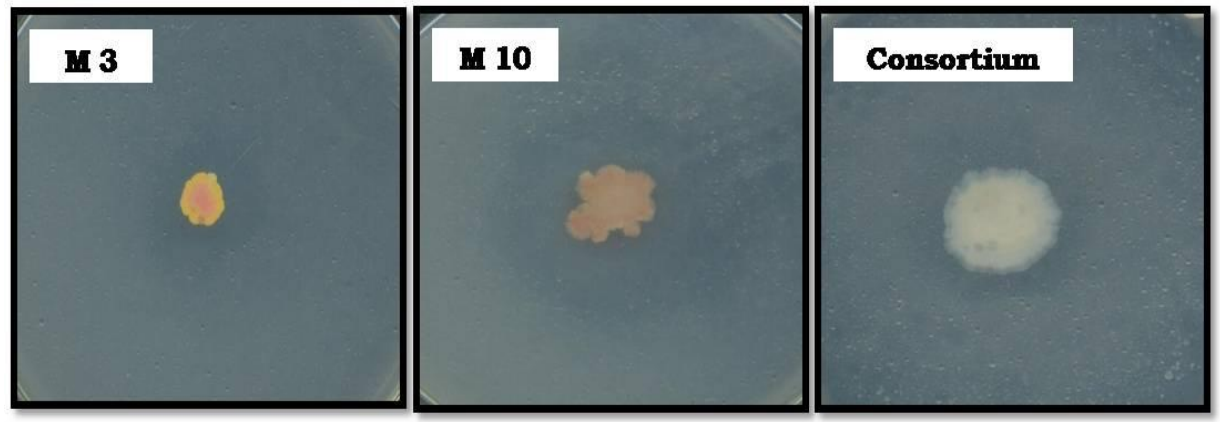

\section{c. Lipase production}

Plate.4 Siderophore and cell wall degrading enzyme production by methylotrophic isolate and consortium

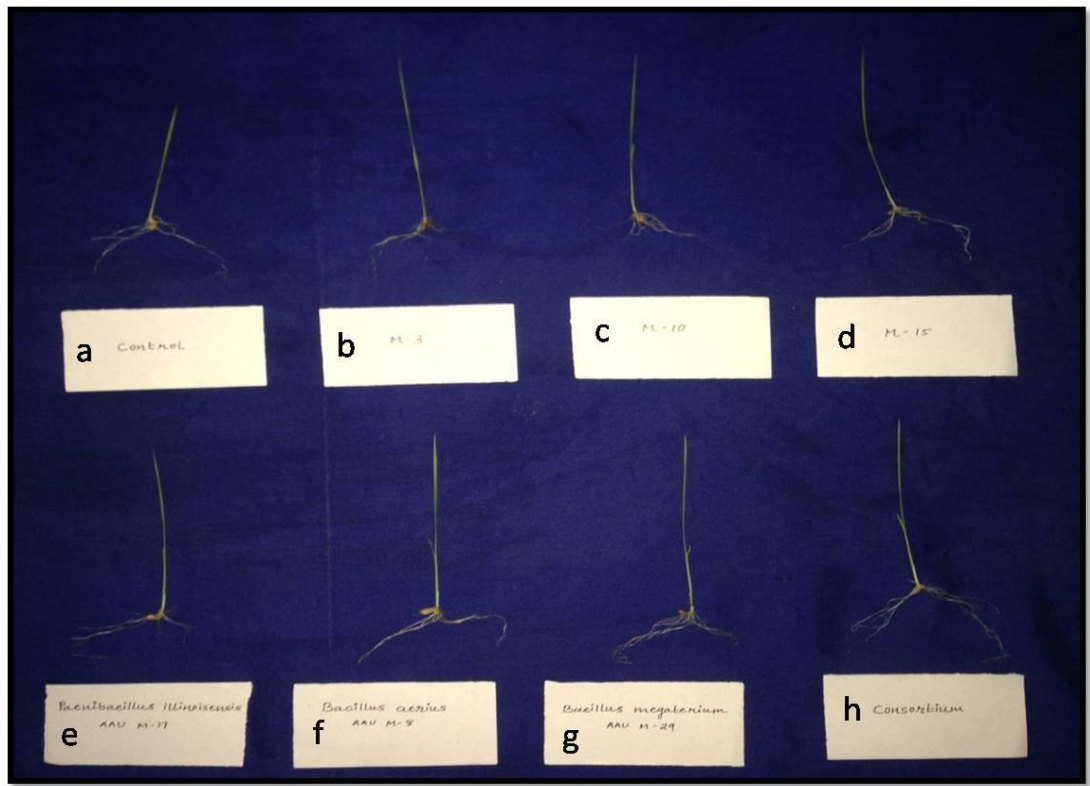

Plate.5 In vitro effect of methylotrophic isolates and their consortium on emerging seedlings of rice $c v$. Gurjari (a) Control, (b) M 3, (c) M 10, (d) M 15, (e) Panibacillus illinoisensis AAU M 17, (f) Bacillus aerius AAU M 8, (g) Bacillus megaterium AAU M 29 and (h) consortium 

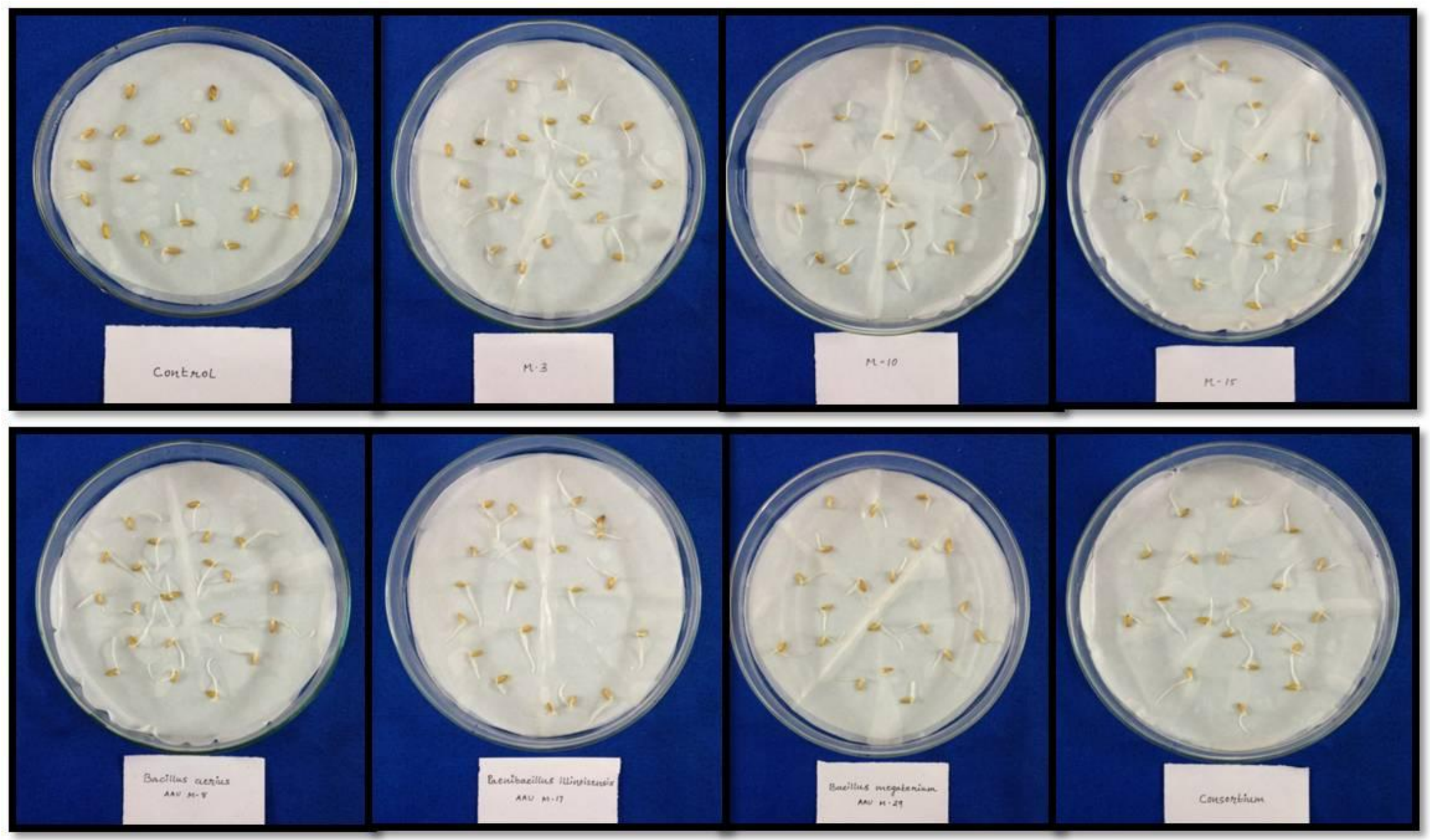

Plate.6 In vitro effect of methylotrophic isolates and consortium on germination of rice seeds $c v$. Gurjari 
The ACC deaminase is useful to plants to fight against several biotic and abiotic stresses such as attack by phytopathogens, salinity, drought and higher concentration of heavy metals, so native methylotrophic bacterial consortium may be useful in rice (Glick et al., 2007).

Enzyme ACC deaminase facilitates plant growth and development under stress condition by decreasing plant ethylene level and thereby protecting plants from stress. It converts ethylene precursor ACC in to 2oxobutanote and NH3. Yim et al., (2010) reported that $M$. oryzae strains CBMB20 and CBMB110 were capable of producing ACC deaminase 94.48 and 24.74 nmol $\alpha$ ketobutyrate mg-1 protein h-1), respectively.

\section{Potash solubilizing efficiency}

Chosen methylotrophic bacterial isolates and their consortium were tested for their potash solubilizing efficiency on Alendreskov's media containing mica as natural ' $\mathrm{K}$ ' substrate. Among all treatments, consortium (4 mm), M 10 (3 mm), M-15 (3 mm), B. aerius AAU M $8(4 \mathrm{~mm})$ and $B$. megaterium AAU M 29 (4 mm) showed potash solubilization efficiency zone diameter $(\mathrm{mm})$ on Alendreskov's mica media plates (Table 4.22).

Biocontrol activity of potential
methylotrophic consortium

\section{Bioassay against plant pathogenic fungi}

Antifungal activity of selected methylotrophic isolates and their consortium on plant pathogenic fungi are presented in Table 4.21. Among all the methylotrophic isolates, $B$. methylotrophicus, B. aerius AAU M 8, B. megaterium AAU M 29 and consortium inhibited growth of Macrophomina spp., Pythium spp., Rhizoctonia spp. and Fusarium spp. on Nutrient-Potato dextrose agar medium whereas isolate $B$. subtilis inhibited growth of Pythium spp., Fusarium spp. and isolate $P$. illinoisensis AAU M 17 inhibited growth of Fusarium spp.

A positive role is played by phyllosphere antagonistic microorganisms, which protect the plants from pathogenic microorganisms and thus improve their healthiness. The inhibition of phytopathogens by PPFM isolates has already been reported by Poorniammal et al., (2010), they have documented that Methylobacterium sp. isolate CO 47 significantly reduced the linear mycelial growth of $R$. solani (Table 4.23).

\section{Siderophore production}

Selected six native isolates and their consortium were found capable of producing siderophores (Table 4.24). All isolates produced yellow-orange colour zone on CAS agar plate hence considered as siderophore producers (Plate 4.11) except $S$. saprophyticus.

Siderophore bind most of the available iron $(\mathrm{Fe}+3)$ in rhizosphere and thereby preventing proliferation of fungal pathogen in immediate vicinity due to lack of iron (Jhala et al., 2015). Lacava et al., (2008) reported 37 strains of Methylobacterium spp. positive on Chrom Azurol Sulphate (CAS) agar for siderophore production. Methylobacterium spp. are producing hydroxamate-type siderophores.

\section{Production of cell wall degrading enzyme}

Selected six native isolates and their consortium were grown on their specific medium. Among them consortium was capable of producing lipase and protease enzyme responsible for cell wall degradation of plant pathogen in vitro (Plate 4.11). S. 
saprophyticus, B. subtilis and B. megaterium produced lipase where as $B$. methylotrophicus was capable to produce protease (Table 4.25).

Madhaiyan et al., (2004b), reported induction of systemic resistance in rice cultivar $\mathrm{Co}-47$ with $17.8 \%$ disease reduction through combined applications of seed imbibition and phyllosphere spray of Methylobacterium sp. and thereby reported increase in content of Phenylalanine Ammonia Lyase (PAL), peroxidase, $\beta$-1,3-glucanase and chitinase activity. Methylobacterium inoculation increased shoot length, number of effective tillers, plant biomass and grain yield as well as protected rice from $R$. solani.

Altogether this result confirms the antagonistic activity of isolates against common soil borne pathogens which benefits the succeeding crops of rice. The antagonistic activity of isolates may be due to their ability to produce Siderophore and cell wall degrading enzymes viz. lipase and protease that degrades lipids which are components of fungal cell wall and thereby have capacity to inhibit their growth.

\section{Plant growth promoting effects of proven isolates on rice cv. Gurjari}

Biopriming of seed by native methylotrophic bacterial isolates with single inoculation as well as combined inoculation (consortium) have significant effect on germination and development of rice cv. Gurjari.

Methylotrophic bacterial isolates, B. subtilis, B. methylotrophicus, B. aerius, $P$. illinoisensis and $B$. megaterium as well as its consortium (combine inoculation) showed $100 \%$ germination while $S$. saprophyticus isolate and control showed $90 \%$ and $80 \%$ germination of Gurjari seeds respectively (Plate 4.12). With regard to seedling vigor index (SVI), consortium of methylotrophic bacterial isolates showed higher SVI (1970.0) followed by B. methylotrophicus, B. aerius, $P$. illinoisensis, B. megaterium, S. saprophyticus and B. subtilis $(1620.0,1500.0,1820.0$, $1820.0, \quad 1750.0$ and 1720.0) respectively compared to control (684.0). All the isolates and its consortium showed increase in seed germination rate as compared to noninoculated seeds which is represented as germination percentage in Table 4.26 and Plate 4.13.

Among all treatments consortium gave the significantly highest root and shoot length $(7.00 \mathrm{~cm}$ and $12.7 \mathrm{~cm})$ compared to single inoculation, $S$. saprophyticus $(6.00 \mathrm{~cm}$ and $12.00 \mathrm{~cm}), B$. subtilis $(4.00 \mathrm{~cm}$ and 11.00 $\mathrm{cm})$, B. methylotrophicus $(6.50 \mathrm{~cm}$ and 11.70 $\mathrm{cm}), B$. aerius $(6.00 \mathrm{~cm}$ and $12.20 \mathrm{~cm}), P$. illinoisensis $(6.50 \mathrm{~cm}$ and $11.00 \mathrm{~cm})$ and $B$. megaterium $(5.50 \mathrm{~cm}$ and $11.70 \mathrm{~cm})$ respectively (Table 4.26, Plate 4.13). Results indicated potential use of bacterial inoculation to reduce the time period required for raising seedlings for transplanted rice cultivation as the seed treated with bacterial isolates showed improved seedling growth parameters.

These result confirms that one or more PGPR traits of methylotrophic bacterial isolates are reflected in overall better growth in laboratory. Moreover, all the isolates were capable of producing IAA which may have played a central role in germination and seedling development as IAA regulator of numerous biological processes like cell division, elongation and differentiation to tropic responses, improves root growth providing a large surface area for nutrient and water uptake which can directly affects seedling development.

In addition, all the isolates showed production of biocontrol molecules such as siderophores, lipase and chitinase enzymes and antagonist to fungi as well as some of them were also 
capable of producing stress release enzyme ACC deaminase, all such parameters may impacted for better seed germination and growth.

Madhaiyan et al., (2005) studied the PPFM inoculation on quality of sugarcane true seed under in vitro conditions wherein inoculated seeds showed increased germination (RG) ranging between 5.14 to 7.18 suggesting that M. extorquens PPFMSo78 strain induced crop growth earlier and better.

\section{Acknowledgements}

We wish to thank Dr. G. B. Patil (Assistant professor) Centre for Advanced Research in Plant Tissue Culture, Department of Agril. Biotechnology, Anand Agricultural University, Anand, Gujarat, India for their help in molecular work and also thank to Mrs. H. N. Shelat (Asso. Research Scientist), krupali Ramanuj (Ph D student) for advice regarding the paper writing and thesis work.

\section{References}

Alexander, D.B. and Zuberer, D.A. 1991. Use of chrome-azurol-S reagents to evaluate siderophore production by rhizosphere bacteria. Biol. Fertil. Soils., 12: 39-45.

Anitha, K.G. 2010. Enhancing seed germination of mono and dicotyledons through IAA production of PPFM. Trends Soil Pl. Sci. J., 1(1): 14-18.

Bremner, J.M. 1958. Determination of nitrogen in soil by the Kjeldahl method. J. Agril. Sci., 55(1): 11-33.

Dworkin, M. and Foster, J. 1958. Experiments with some microorganisms which utilize ethane and hydrogen. $J$. Bacteriol., 75: 592-601.

Dabhi, B.K., Vyas, R.V. and Shelat, H.N. 2014. Use of Banana Waste for the Production of Cellulolytic Enzymes under Solid Substrate Fermentation
Using Bacterial Consortium. Int. J. Curr. Microbiol. App. Sci., 3(1): 337346.

Esitken, A., Pirlak, L., Turan, M. and Sahin, F. 2006. Effects of floral and foliar application of plant growth promoting rhizobacteria (PGPR. on yield, growth and nutrition of sweet cherry. Sci. Horti., 110: 324-327.

Foldes, T., Banhegyi, I., Herpai, Z., Varga, L. and Szigeti, J. 2000. Isolation of Bacillus strains from the rhizosphere of cereals and in vitro screening for antagonism against phytopathogenic, food-borne pathogenic and spoilage micro-organisms. J. App.l Microbiol., 89: 840-846.

Glick, B.R., Todorovic, B., Czarny, J., Cheng, Z.Y., Duan, J. and McConkey, B. 2007. Promotion of plant growth by bacterial ACC deaminase. Critical Rev. in Pl. Sci., 26(5-6): 227-242.

Haque, A.H., Akon, M.M., Islam, M.A., Khalequzzaman, K.M. and Ali, M.A. 2007. Study of seed health, germination and seedling vigor of farmers produced rice seeds. Int. J. Sustain. Crop Prod., 2(5): 34-39.

Hu, X.F., Chen, J. and Guo, J.F. 2006. Two phosphate and potassium solubilizing bacteria isolated from Tiannu mountain, Zhejiang, China. World J. Micro. Biotech., 22: 983-990.

Ibrahim, A.S.S. and El-diwany, A.I. 2007. Isolation and identification of new cellulases producing thermophilic bacteria from an egyptian hot spring and some properties of the crude enzyme. Aus. J. Basic and Appl. Sci., 1(4): 473478.

Jackson, M.L. 1973. Soil chemical analysis. Prentice hall of India Pvt. Ltd., New Delhi. Soil and Crop, 14(1): 9-11.

Jha, B.K., Pragash, M.G., Cletus, J., Raman, G. and Sakthivel. 2009. Simultaneous phosphate solubilization potential and 
antifungal activity of new fluorescent Pseudomonas strains, P. aeruginosa, $\mathrm{P}$. plecoglossicida and P. mosselii. World J. Microbiol. Biotechnol., 25: 573-581.

Jhala, Y.K., Vyas, R.V., Panpatte, D. G. and Shelat H.N. 2015. Rapid Methods for Isolation and Screening of Methane Degrading Bacteria. J. Bioremed. Biodeg., 2015, 7(1): 1-5.

Khalid, A., Arshad, M. and Zahir, Z. A. 2004. Screening plant growth-promoting rhizobacteria for improving growth and yield of wheat. J. Appl. Microbiol., 96: 473-480.

Kutschera, U. 2007. Plant-associated methylobacteria as co-evolved phytosymbionts. Pl. Signal. and Behav., 2: 74-78.

Lacava, T., Silva-Stenico, M.E., Araújo, W. L., Simionato, AV.C., Carrilho, E., Tsai, S. M. and Azevedo, J.L. 2008. Detection of siderophores in endophytic bacteria Methylobacterium spp. associated with Xylella fastidiosa sub sp. Pauca. Pesq. agropec. bras., Brasília, 43(4): 521-528.

Lawrence, R.C., Fryer, T.F. and Reiter, B. 1967. Rapid method for the quantitative estimation of microbial lipases. Nat., 213: 1264-1265.

Madhaiyan, M., Poonguzhali, S., Lee, H.S., Hari, K., Sundaram, S.P. and Sa, T.M. 2005. Pink-pigmented facultative methylotrophic bacteria accelerate germination, growth and yield of sugarcane clone Co86032 (Saccharum officinarum L). Biol. Fert. Soils, 41: 350-358.

Madhaiyan, M., Poonguzhali, S., Senthilkumar, M., Seshadri, S, Chung, H.Y., Yang, J.C. 2004b. Growth promotion and induction of systemic resistance in rice cultivar Co-47 (Oryza sativa L). by Methylobacterium spp. Bot. Bul Academia Sinica., 45: 315324.
Poly, F., Ranjard, L., Nazaret, S., Gourbiere, F. and Monrozier, L.J. 2001. Comparison of nifH gene pools in soils and soil microenvironments with contrasting properties. Appl. Environ. Microbiol., 67: 2255-2262.

Poorniammal, R., Sundaram, S.P. and Kumutha, K. 2010. In vitro biocontrol activity of Methylobacterium Extorquens against fungal pathogens. Inter. J. Plant Prot., 2(1): 59-62.

Sambrook, J., Fritsch, E.F. and Maniatis, T. 1989. Molecular cloning: a laboratory manual, 2nd Ed. Cold Spring Harbor Laboratory, Cold Spring Harbor, N.Y.

Satapute, P.P., Olekar, H.S., Shetti, A. A., Kulkarni, A.G., Hiremath, G.B., Patagundi, B.I., Shivsharan, C.T. and Kaliwal, B.B. 2012. Isolation and characterization of nitrogen fixing bacillus subtilis strain As-4 from agricultural soil. Intern. J. Recent Scient. Res., 3(9): 762 -765.

Sateesh, G. and Sivasakthivelan, P. 2013. Studies on the influence of bioinoculants consortium on chilies and its effects on soil health management. Intern. J. Chem. Tech. Res., 5(3): 13261328.

Smibert, R.M. and Krieg, N.R. 1994. Phenotypic characterization. In: Gerhardt, P., Murray, R.G.E., Wood, W.A. and Krieg, N.R. ed. Methods for general and molecular bacteriology. Am. Soci. of Microbiol., Washington, DC: 607-654.

Yim, W.J., Chauhan, P.S., Madhaiyan, M., Tipayno, S.C. and Sa, T. 2010. Plant growth promontory attributes by 1aminocyclopropane-1-carboxylate (ACC. deaminase producing Methylobacterium oryzae strains isolated from rice. Proceeding of 19th world congress on soil sciences, pp. 9699. 


\section{How to cite this article:}

Ronak R. Prajapati, Y.K. Jhala and Vyas R.V. 2017. In vitro Study of Plant Growth Promoting Methylotrophic Bacterial Consortium as a Plant Probiotics for Paddy. Int.J.Curr.Microbiol.App.Sci. 6(5): 2608-2626. doi: https://doi.org/10.20546/ijcmas.2017.605.294 